\title{
Dietary nitrite supplementation improves insulin resistance in type 2 diabetic KKAy mice
}

Kazuo Ohtake ${ }^{1}$, Genya Nakano ${ }^{1}$, Nobuyuki Ehara ${ }^{1}$, Kunihiro Sonoda ${ }^{2}$, Junta Ito $^{3}$, Hiroyuki Uchida ${ }^{1}$, and Jun Kobayashi ${ }^{1}$

${ }^{1}$ Division of Pathophysiology, Department of Clinical Dietetics and Human Nutrition, Faculty of Pharmaceutical Science, Josai University, Saitama, Japan

${ }^{2}$ Department of Food and Nutritional Environment, College of Human Life and Environment, Kinjo

Gakuin University, Nagoya, Japan

${ }^{3}$ Division of Oral Anatomy, Department of Human Development and Fostering, Meikai University

School of Dentistry, Saitama, Japan,

\begin{abstract}
BACKGROUND: Because insulin signaling is essential for endothelial nitric oxide synthase (eNOS)-derived nitric oxide (NO) production, loss of bioavailable NO might be a common underlying molecular mechanism for the development of insulin resistance and endothelial dysfunction. Although dietary nitrite act as a substrate for systemic NO generation, serving as physiological alternative source of NO-based signaling, it is not known how dietary nitrite affects type 2 diabetes mellitus. We report therapeutic effects of dietary nitrite on the metabolic and histological features of KKAy diabetic mice.

METHODS: KKAy mice were divided into 3 groups (without nitrite, $50 \mathrm{mg} / \mathrm{L}$, and $150 \mathrm{mg} / \mathrm{L}$ nitrite in drinking water), and 2 groups of C57BL/6J as controls (without nitrite and $150 \mathrm{mg} / \mathrm{L}$ nitrite in drinking water). After 10 weeks, blood samples, visceral adipose tissues and gastrocnemius muscles were collected following 16 hours fasting for the assessment of homeostasis model assessment of insulin resistance (HOMA-IR), histology of adipose tissue, insulin-stimulated sequential signaling to glucose transporter 4 (GLUT4), and nitrite and nitrate contents in the muscle using HPLC system.
\end{abstract}

RESULTS: KKAy mice developed obesity with enhanced fasting plasma levels of glucose and insulin, and exhibited increased HOMA-IR score compared to C57BL/6J control mice. Dietary nitrite dose-dependently reduced the size of hypertrophic adipocytes and TNF- $\alpha$ transcription in the adipose tissue of KKAy diabetic mice, which also restored insulin-mediated signal transduction including p85 and Akt phosphorylation and subsequent GLUT4 expression in skeletal muscles.

CONCLUSIONS: These results suggest that dietary nitrite provides an alternative source of NO, and subsequently improving insulin-mediated signaling pathway and the metabolic and histological features in KKAy diabetic mice.

Keywords: dietary nitrite/nitrate, insulin resistance, type 2 diabetes mellitus, glucose transporter 4 .

\section{Introduction}

Insulin affects cells through binding to its receptor on the surface of insulin-responsive cells regulating glucose homeostasis. In addition, the signaling pathway linking the insulin receptor to activation of endothelial nitric oxide synthase (eNOS) in vascular endothelium also has been recognized (Abel 2004, Lundberg 2009, Das 2003, Wang 2013). Therefore, there is reciprocal relationship between insulin resistance and endothelial dysfunction in the pathophysiology underlying diabetes and metabolic syndrome (Kim 2006). Recent accumulating evidence has suggested that polymorphism in the eNOS gene is associated with development of metabolic 
syndrome in humans (Fernandez ML 2004, Monti LD 2003), and eNOS-deficient mice display a number of features of metabolic syndrome characterized by hypertension, dyslipidemia, and insulin resistance (Gonzalez-Sánchez 2007, Duplain 2001), indicating that loss of bioavailable nitric oxide (NO) might be a common underlying molecular mechanism for the development of metabolic syndrome and insulin resistance (Sansbury 2014). It would be therefore reasonable to consider exogenous NO donor as a pharmacologic agent for the prevention and treatment of type 2 diabetes mellitus.

It is well accepted that dietary nitrate and nitrite act as a substrate for systemic NO generation, serving as physiological alternative source of NO-based signaling especially when endogenous NOS-derived NO is lacking (Bryan NS 2005). However, there are few reports showing beneficial effects of dietary nitrite/nitrate on type 2 diabetes mellitus (Carlstrom 2010, Mohler 2014). In the present study, first we characterized KKAy mice as type 2 diabetic animal model in comparison to $\mathrm{C} 57 \mathrm{BL} / 6 \mathrm{~J}$ control mice in terms of insulin resistance, visceral adipose tissues and insulin-stimulated signaling process to glucose transporter 4 (GLUT4) expression. We then sought to investigate whether dietary nitrite supplementation would reverse the metabolic and histological features of KKAy diabetic mice and consequently improve insulin resistance.

\section{Material and methods}

\section{2-1. Animals}

Specific pathogen-free male KKAy and C57BL/6J mice, 3 week of age from CLEA Japan, Inc. (Tokyo, Japan) were allowed food (CE-2, CLEA Japan) and reverse osmosis (RO) water ad libitum, and were kept on a 12/12 h light/dark cycle with at least 7 days of local vivarium acclimatization before experimental use. All the protocols were approved by the Institutional Animal Care and Use Committee at the University of Josai Life Science Center (H22040) and were consistent with the Guide for the Care and Use of Laboratory Animals published by the NIH.

\section{2-2. Experimental procedures}

Starting at 4 weeks of age, KKAy mice were divided into 3 groups: without nitrite $\left(\mathrm{KKA}^{\mathrm{y}}-0 \mathrm{mg} / \mathrm{L}\right.$, $\mathrm{n}=10), 50 \mathrm{mg} / \mathrm{L}\left(\mathrm{KKA}^{\mathrm{y}}-50 \mathrm{mg} / \mathrm{L}, \mathrm{n}=10\right)$, and $150 \mathrm{mg} / \mathrm{L}$ nitrite $\left(\mathrm{KKA}^{\mathrm{y}}-150 \mathrm{mg} / \mathrm{L}, \mathrm{n}=10\right)$ in drinking water, 2 groups of C57BL/6J as controls: without nitrite $(\mathrm{C} 57 \mathrm{BL} / 6 \mathrm{~J}-0 \mathrm{mg} / \mathrm{L}, \mathrm{n}=8)$ and $150 \mathrm{mg} / \mathrm{L}$ nitrite $(\mathrm{C} 57 \mathrm{BL} / 6 \mathrm{~J}-150 \mathrm{mg} / \mathrm{L}, \mathrm{n}=8)$ in drinking water. The mice were housed in individual cages in a temperature- and humidity controlled room. Obesity was confirmed by checking body weight (once at a week), food intake (once at a week) and casual blood glucose levels (once at 2 weeks) for 10 week experimental periods. Casual blood glucose levels were determined with Glucocard ${ }^{\mathrm{TM}}$ (GT-1661, Arkray, Inc., Kyoto, Japan). Blood samples were obtained from the cut tip of the tail.

At 13 weeks of age, intraperitoneal glucose tolerance tests (IPGTT) were performed. Following overnight fast, animals were administered intraperitoneal dose of $20 \%$ glucose solution $(1.5 \mathrm{~g} / \mathrm{kg})$. Blood samples were collected from tail vein before and 15, 30, 60, 90, 120 min after injection.

At 14 weeks of age, the animals were anesthetized with an intraperitoneal injection of pentobarbital $(60 \mathrm{mg} / \mathrm{kg})$ following 16 hours fasting period. To determine the homeostasis model assessment as an index of insulin resistance (HOMA-IR), blood samples (about $200 \mu \mathrm{L}$ ) were collected from tail vein before necropsy. Blood glucose levels were determined with Glucocard ${ }^{\mathrm{TM}}$ (GT-1661, Arkray, Inc., Kyoto, Japan). Plasma insulin concentrations were determined with Mouse Insulin ELISA kit (Shibayagi, Gunma, Japan). HOMA-IR was calculated as fasting plasma glucose $[\mathrm{mmol} / \mathrm{l}] \times$ fasting plasma insulin [mU/l] / 22.5 (Liu 2010). Thereafter, animals were intraperitoneally administered insulin $(10 \mathrm{U} / \mathrm{kg}$, diluted in saline $)$. This produced a maximal sustained increase in IR, IRS-1, and p85 phosphorylation within 5 min (Ishizuka 1999). At 5 min after injection, Gastrocnemius muscles and visceral adipose tissues were then excised from insulin 
injected animals and frozen immediately at $-80^{\circ} \mathrm{C}$ until use. Visceral adipose tissues were weighed and stored at $-80^{\circ} \mathrm{C}$ until use or fixed in $10 \%(\mathrm{w} / \mathrm{v})$ neutral buffered formalin solution.

\section{2-3. RT-PCR}

Adipose tissue samples stored at $-80^{\circ} \mathrm{C}$ were extracted using RNeasy Lipid Tissue Mini kit (QIAGEN) according to the manufacturer's instructions. Total RNA concentrations were quantified by NanoDrop (Thermo Fisher Scientific ${ }^{\mathrm{TM}}$ ). RT-PCR was performed with $1 \mu \mathrm{g}$ of total RNA by use of Gene RED PCR Mix (NIPPON GENE) according to the manufacturer's instructions: 1 cycle at $42^{\circ} \mathrm{C}$ for $40 \mathrm{~min}, 95^{\circ} \mathrm{C}$ for $5 \mathrm{~min}$, and $4^{\circ} \mathrm{C}$ for $5 \mathrm{~min}$ for reverse transcription; and 22-34 cycles at $94^{\circ} \mathrm{C}$ for $30 \mathrm{~s}, 60^{\circ} \mathrm{C}$ for $30 \mathrm{~s}$, and $72^{\circ} \mathrm{C}$ for $1 \mathrm{~min}$ for PCR. PCR was performed with a RoboCycler 96 gradient temperature cycler (Stratagene). The oligonucleotides used as primers were synthesized by FASMAC (Kanagawa, Japan). The primer pairs were designed as follows, GAPDH: forward primer, $5^{\prime}$-agaacatcatcctgcatcc' ${ }^{\prime}$,reverse primer, $5^{\prime}$-tccaccacctgttgctgta-3' (367 bp, 22 cycle), TNF- $\alpha$ : forward primer, $5^{\prime}$-ggcaggtctactttggagtcattgc ' , reverse primer, 5 -acattcgaggctccagtgaattcgg-3 ${ }^{\prime} \quad(300 \mathrm{bp}, 34$ cycle $)$, MCP-1: forward primer, $5{ }^{\prime}$ -actgaagccagctctctcttcctc' ${ }^{\prime}$, reverse primer, $5^{\prime}$-ttccttcttggggtcagcacagac-3' $3^{\prime}$ (274 bp, 28 cycle). Target mRNA expressions were quantified relative to the expression of GAPDH. A portion of each PCR mixture was electrophoresed in $2 \%$ agarose gel in TBE buffer ( $89 \mathrm{mM}$ Tris, $89 \mathrm{mM}$ boric acid, 2 mM EDTA, $\mathrm{pH} 8.3$ ), and the gel was visualized by ethidium bromide staining. The intensity of the PCR products was measured using a Gene Genius Bioimaging System (Syngene).

\section{2-4. Histological analysis}

Adipose tissues were fixed in 10\% neutral buffered formalin solution and embedded in paraffin. Sections $(8 \mu \mathrm{m})$ were stained with hematoxylin and eosin (HE) for light microscopic observation at magnification $\times 200$. The area and size distribution of adipocyte were measured in 500 cells $/ 20$ fields / mouse ( $\mathrm{n}=4$ /groups) using the Image $\mathrm{J}$ software program (Okuno 1998). Digital images were obtained from a high-resolution digital camera system (Penguin 150CL, Pixera, Los Gatos, CA, USA) linked to a microscope (BX41, Olympus, Tokyo, Japan) and desktop computer (Pentium 4, 2.0 $\mathrm{GHz}$ ).

\section{2-5. Western blot analysis}

The plasma membrane fraction (used for detecting GLUT4 translocation) and tissue lysate (used for detecting PI3/Akt signaling) were prepared from skeletal muscle as described previously (Dang 2010). Briefly, tissue samples were homogenized in 10 volumes of ice-cold lysis buffer A (10 mM Tris- $\mathrm{HCl}$ at $\mathrm{pH} 7.8,10 \mathrm{mM} \mathrm{KCl}, 1.5 \mathrm{mM} \mathrm{MgCl} 2,1 \mathrm{mM}$ phenylmethylsulfonylfluoride, $0.5 \mathrm{mM}$ dithiothreitol, $5 \mu \mathrm{g} / \mathrm{mL}$ of aprotinin and $10 \mu \mathrm{g} / \mathrm{mL}$ of leupeptin) and lysed with 10 volumes of buffer A with $0.1 \%$ Nonidet P-40, and passed through a 22 -gauge needle three times. The homogenate was spun at $1,000 \mathrm{~g}$ for $10 \mathrm{~min}$ at $4^{\circ} \mathrm{C}$. The plasma membrane fraction was obtained by resuspending the obtained pellet in buffer A containing 1\% Nonidet P-40, and centrifuging at 100,00g for 20 min at $4^{\circ} \mathrm{C}$. To obtain the whole tissue lysate, skeletal muscle was homogenized in 10 volumes of buffer A and lysed with 10 volumes of buffer B $(10 \mathrm{mM}$ Tris- $\mathrm{HCl}$ at $\mathrm{pH} 8.0,150 \mathrm{mM} \mathrm{NaCl}, 1 \%$ Nonidet P-40, $0.5 \%$ sodium deoxycholate, $0.1 \%$ SDS, $0.5 \mathrm{mM}$ DTT, $1 \mathrm{mM}$ phenylmethylsulfonylfluoride, $0.5 \mathrm{mM}$ dithiothreitol, $5 \mu \mathrm{g} / \mathrm{mL}$ of aprotinin and $10 \mu \mathrm{g} / \mathrm{mL}$ of leupeptin). Both the plasma membrane fraction and the whole tissue lysates typically contained $4 \mathrm{mg}$ protein per $\mathrm{ml}$ on the basis of the BCA protein assay. Protein samples (20 $\mu \mathrm{g}$ protein/lane) were resolved by SDS-PAGE, electroblotted to PVDF membranes, and immunoblotted with selected antibodies against PI3 kinase p85 (Cell Signaling Technology), p85-Tyr ${ }^{458}$ (Cell Signaling Technology), Akt (Cell Signaling Technology), Akt-Ser ${ }^{473}$ (Cell Signaling Technology), GLUT4 (Santa Cruz Biotechnology), GAPDH (Santa Cruz Biotechnology). Bound antibody was visualized using the ECL chemiluminescence detection system 
(SuperSignal West Dura Extended Duration Substrate, Pierce) with HRP-conjugated secondary antibodies (Pierce). The band intensity was quantified using a Bio Imaging System, with Gene Snap and Gene Tools software (Syngene Bio Imaging, Cambridge, USA).

\section{2-6. Nitrite and nitrate concentrations in the skeletal muscle}

Nitrite and nitrate concentrations in the skeletal muscle were measured using a dedicated HPLC system (ENO-20; EiCom, Kyoto, Japan) (Ohtake 2007, Ohtake 2010). This method is based on the separation of nitrite and nitrate by ion chromatography, followed by on-line reduction of nitrate to nitrite, postcolumn derivatization with Griess reagent, and detection at $540 \mathrm{~nm}$. Proteins in each sample were removed by centrifugation at $10,000 \mathrm{~g}$ for 5 min following methanol precipitation (muscle:methanol $=1: 2$ weight/volume, $4^{\circ} \mathrm{C}$ ).

\section{2-7. Statistical analysis}

All values are expressed as means \pm SE. Data were analyzed by two-way ANOVA, and then differences among means were analyzed using the Tukey-Kramer multiple comparison test. A level of $P<0.05$ was considered significant.

\section{Results}

\subsection{Time course of changes in body weight, food intake, and fasting blood glucose levels}

In comparison to $\mathrm{C} 57 \mathrm{BL} / 6 \mathrm{~J}$ groups, KKAy groups showed remarkable increases in body weight, food intake and casual blood glucose levels at the designated time points over the course of the study (Fig. 1a-c), presenting the characteristic features of type 2 diabetes such as obesity and hyperglycemia. Whereas, nitrite treatment had no impact on the changes in body weight, food intake and casual blood glucose levels either in KKAy groups or in C57BL/6J groups.

\subsection{Effects of dietary nitrite on glucose metabolism and insulin sensitivity}

Figure 2 a shows the time course of blood glucose levels following IPGTT performed at the end of the experimental day after 16 hours fasting. The blood glucose levels of KKAy groups were significantly higher than C57BL/6J groups from 30min to $120 \mathrm{~min}$ after IPGTT, showing impaired glucose tolerance, however among KKAy groups there was a tendency of decrease in blood glucose levels in KKAy-150 compared to KKAy-0 at each time period (statistically significant at $90 \mathrm{~min}$ ). Similarly, the AUC (area of the glucose metabolic clearance rate following IPGTT) of KKAy-0 was more than C57BL/6J control groups, and apparently reduced with dietary nitrite in KKAy-150 group (Fig. 2b). We also measured HOMA-IR calculated from the fasting plasma levels of glucose and insulin (Fig. 3a and b). Consistent with the results of IPGTT, HOMA-IR exhibited insulin resistance in KKAy-0 group, which was improved with dietary nitrite both in KKAy-50 and -150 (Fig. 3c).

\subsection{Effects of dietary nitrite on the adipose tissue morphology}

We next investigated the effect of dietary nitrite on the adipose tissue mass and the size of adipocytes in KKAy mice. The ratio of adipose tissue mass to body weight was significantly higher in KKAy groups than C65BL/6J groups (Fig. 4a), while dietary nitrite had no impact on this ratio either in KKAy or in C65BL/6J group. On the other hand, histological analyses of fat tissue revealed that adipocyte size of KKAy-0 was larger than that of C57BL/6J groups and dose-dependently reduced with dietary nitrite in KKAy-50 and -150 groups (Fig. 4b). Qualitative analysis of adipocyte size revealed a wide distribution of cell frequency and tendency to spread toward the larger sizes in KKAy-0 group, while comparing with KKAy-0 group, the analysis showed an increasing frequency of small adipocytes $\left(\operatorname{area}<10,000 \mu \mathrm{m}^{2}\right)$ and decreasing wide distribution of larger adipocytes (area $>10,000 \mu \mathrm{m}^{2}$ ) in KKAy-50 and -150 groups (Fig. 4c). 


\subsection{Effects of dietary nitrite on the transcription of proinflammatory cytokines in visceral fat tissues}

We examined the relation of hypertrophic phenotype change of adipocyte to proinflammatory state of fat tissue and also examined the anti-inflammatory effect of dietary nitrite. Unfortunately we could not observe a significant suppression of the transcriptional level of MCP-1 (Fig. 5a), whereas dietary nitrite obviously reduced the transcriptional level of TNF- $\alpha$ in adipose tissue (Fig. 5b).

\subsection{Sequential phosphorylation of p85/Akt and subsequent expression of GLUT4 on the cell membrane of skeletal muscle}

We then evaluated the effect of dietary nitrite on the PI3K-Akt-GLUT4 signaling pathway (insulin receptor-mediated signaling pathway) in skeletal muscle. In figure 6, the upper panels show Western blots of each signaling protein (data are representative of three independent experiments). The band intensities were quantified by densitometry, and the ratios of the levels of phosphorylated to total protein were determined as p85-Tyr ${ }^{458}$ to p85 (Fig. 6a) and Akt-Ser ${ }^{473}$ to Akt (Fig. 6b), and the ratio of the expression level of GLUT4 to housekeeping protein GAPDH was also determined as GLUT4 to GAPDH (Fig. 6c). Despite no statistical difference in p85 phosphorylation among KKAy groups (Fig. 6a), dietary nitrite exhibited a tendency to increase the insulin-stimulated phosphorylation of the regulatory p85 subunit of PI3K compared to untreated KKAy-0 group and this increasing tendency was significantly amplified in the subsequent Akt phosphorylation of KKAy-50 and -150 groups with dietary nitrite (Fig. 6b), and which was followed by the increase in GLUT4 expression on cell membrane of skeletal muscle (Fig. 6c).

\subsection{Nitrite and nitrate levels in skeletal muscle}

Because it is difficult to measure NO production directly in vivo, we instead measured skeletal muscle levels of nitrite and nitrate (stable NO oxidation products indicative of the level of accumulated NO production in the fasting condition) after 16 hours fasting. Interestingly, tissue levels of nitrite (immediate NO oxidation product) in non-treated KKAy mice was significantly lower than $\mathrm{C} 57 \mathrm{BL} / 6 \mathrm{~J}$ control mice, suggesting reduced NO production and bioavailability in diabetic state. However, dietary nitrite improved insulin resistance by restoring tissue levels of nitrite and nitrate (Fig. 7).

\section{Discussion}

Adipose tissue is necessary for normal secretion of adipokines such as leptin and adiponectin which enhance insulin sensitivity. Impaired secretion of such adipokines observed in lipodystrophy of human and mouse raises plasma levels of TG and FFAs, causing insulin resistance (Guerre-Millo 2004). On the contrary, enlarged adipocyte in obesity produces another kind of adipokines such as MCP-1 and TNF- $\alpha$, which increase lipolysis in adipose tissues and release FFAs into the circulation, finally leading to insulin resistance and type 2 diabetes mellitus.

In the present study, as increased adiposity develops in KKAy diabetic mice (Fig 4a, b), the transcriptional levels of MCP-1 and TNF- $\alpha$ become higher in adipocytes of KKAy-0 mice than C57BL/6J control mice (Fig 5a, b). We qualitatively analyzed the sizes of adipocyte using the histogram of cell size distribution, which revealed a wider distribution of cell frequency and a tendency to spread toward the larger sizes in KKAy-0 group than in C57BL/6J control mice, the cells of which were mainly composed of small adipocytes (Fig. 4c). The phenotypic changes of adipocytes in the diabetic mice are closely associated with the increased transcriptional levels of MCP-1 and TNF- $\alpha$ in adipocytes (Fig. 5). These proinflammatory cytokines and FFAs modulate systemic inflammatory responses through the TLR4-mediated mechanism (Reyna 2008). It is well known that TLR4-mediated NF- $\kappa \mathrm{B}$ activation is inhibited by NO via S-nitrosylation of cysteine residue of Ikk $\beta$ and NF-kB itself, which thereby causes inhibition of $\mathrm{I} \kappa \mathrm{B} \alpha$ phosphorylation and NF-kB binding to 
DNA, respectively (Hess 2005). Then, this could inhibit transcription of the inflammatory cytokines including MCP-1 and TNF- $\alpha$ in adipocytes (Fig. 5a, b). Similarly in the present study, dietary nitrite dose-dependently shifted the cell frequency to the smaller size distribution in KKAy diabetic mice (Fig. 4c), which is obviously consistent with the decrease in TNF- $\alpha$ transcription in adipose tissues with dietary nitrite.

As increased adiposity is supposed to be a cause of subsequent systemic inflammation, it causes excessive ROS production and oxidative shift in the intracellular redox environments (de Luca 2008). Recent evidence indicated that the defect responsible for insulin resistance lies mostly at the post-receptor level of insulin signaling (Draznin 2006). Because many kinases and phosphatases associated with insulin signaling pathway are intricately, but delicately regulated and balanced by protein phosphorylation, dephosphorylation, and in addition, nitrosylation (Fisher-Wellman 2012). Excessive NO production by iNOS $S$-nitrosylates the proteins such as IRS-1 and Akt involved in the early steps of the insulin transduction pathway, and this results in insulin resistance in skeletal muscle (Carvalho-Filho 2005). On the other hand, physiological levels of NO not only induces microvascular vasodilatation for the effective insulin transport to the target cells, but also mediates $S$-nitrosylation of protein-tyrosine phosphatase 1B (PTPB1) (Wang 2013) and enhancing insulin action. Because PTPB1 dephosphorylates insulin receptor and its substrates, then attenuating insulin action, its phosphatase activity usually tends to be suppressed by eNOS-mediated $S$-nitrosylation. Whereas once vascular eNOS activity is impaired as seen in diabetes and metabolic syndrome, PTPB1 suppresses the downstream signaling to $\mathrm{PKB} / \mathrm{Akt}$, then leading to insulin resistance. Thus, NO might act as a regulating factor for the downstream signaling linking to GLUT4 translocation and glucose uptake (Hsu 2010, Richey 2013). In addition, as shown in the present study, Jiang recently reported the GLUT4-mediated mechanism in dietary nitrite-induced improvement of insulin resistance, in which they demonstrated that NO-dependent nitrosylation of GLUT4 itself facilitates GLUT4 translocation to the membrane for glucose uptake and thereby improving insulin resistance (Jiang 2014). In the present study we have not examined nitrosative modification of these signal-related proteins and the evidence concerning these issues so far remains poor, but this might be a possible mechanism by which dietary nitrite consequently recover the insulin-stimulated phosphorylation of the p85 and Akt as well as the expression of GLUT4 and glucose metabolism in the skeletal muscles (Fig 6 a-c).

In addition to the NO-mediated mechanisms mentioned above, NO is also reported to play important roles in the suppression of the development of insulin resistance at various levels and conditions including mitochondrial function (Larsen 2011), insulin secretion (Nystrom 2012), insulin transport (Wang 2013), glucose uptake (Khoo 2014), and modulation of inflammation (Rizzo 2010). Recent accumulating data has indicated that loss of NO bioavailability might be a pivotal underlying molecular mechanism for the development of insulin resistance (Carlstrom 2010, Kashyap 2005). In agreement with these proposals, the present study also showed a significant decrease in the nitrite levels in the skeletal muscle of KKAy diabetic mice compared to C57BL/6J control mice (Fig. 7), suggesting that the decrease in NO bioavailability in the skeletal muscle of the diabetic mice is also observed in the present study. Dietary nitrite supplementation increases the nitrite levels of skeletal muscle, then contributing to the subsequent improvements of the metabolic and histological features of KKAy diabetic mice.

To apply this strategy to the clinical setting, we also have to consider the food sources of nitrate/nitrite. According to the report by Hord (Hord 2009) in which daily nitrate intakes were calculated based on the variations by using the vegetable and fruit components of the Dietary Approaches to Stop Hypertension (DASH) dietary pattern (Lin PH 2003), the daily nitrate intake easily exceeds $1200 \mathrm{mg}$ /day nitrate. Approximately $25 \%$ of ingested nitrate is secreted in saliva, and $20 \%$ of the secreted nitrate in saliva is converted to nitrite by commensal bacteria on the tongue (Lundberg JO, 1994), indicating about 5\% of the originally ingested nitrate is swallowed into stomach (Archer 2002). If you have DASH diet containing $1200 \mathrm{mg}$ nitrate, you are supposed to 
swallow $46 \mathrm{mg}$ nitrite a day. When considering an application of this treatment to clinical practice, the amounts of nitrite the mice drank in the present study totaled approximately 0.1 and $0.3 \mathrm{mg} / \mathrm{day}$ for mouse (the lower dose: $50 \mathrm{mg} / \mathrm{L}$ and the higher dose of nitrite: $150 \mathrm{mg} / \mathrm{L}$, respectively, based on drinking $2 \mathrm{ml}$ of water/mouse/day). These doses of nitrite $(2$ and $6 \mathrm{mg} / \mathrm{kg} / \mathrm{day}$, calculated as $50 \mathrm{~g}$ body weight/mouse) could be orally achievable through increasing consumption of nitrate/nitrite-rich foods and vegetables (Bryan 2007), providing a possible therapeutic strategy for the diabetic patients. Because we have not observed any fetal side effects such as methemoglobinemia and hypotension in this mouse model, we have not measured methemoglobin levels and blood pressure. Instead, we previously reported a mouse model for experimental colitis treated with $25 \mathrm{mmol} / \mathrm{L}$ sodium nitrite in drinking water (approximately 35- and 12-fold concentrated nitrite compared to those of the present study), whereas even in that doses, no measurable effects on methemoglobin levels and blood pressure were observed (Ohtake 2010). Carcinogenesis is another concern attributed to nitrite/nitrate, however, today, no causative link between nitrite/nitrate exposure and cancer including stomach cancer has been documented in humans (Bryan 2012).

In conclusion, these results suggest that endogenous NO defect might underlie the development of insulin resistance, therefore dietary nitrite provides an alternative source of $\mathrm{NO}$, and subsequently improving insulin-mediated signaling pathway and the metabolic and histological features in KKAy diabetic mice.

\section{Acknowledgment}

This work was supported by the research grant from the Japan Food Chemical Research Foundation to Dr. Ohtake.

\section{References}

Abel ED. Insulin signaling in heart muscle: lessons from genetically engineered mouse models. Curr Hypertens Rep, 6: 416-423, 2004.

Aguirre V, et al. The c-Jun NH(2)-terminal kinase promotes insulin resistance during association with insulin receptor substrate-1 and phosphorylation of Ser(307). J Biol Chem, 275: 9047-9054, 2000 .

Aguirre, V., et al. Phosphorylation of Ser307 in insulin receptor substrate-1 blocks interactions with the insulin receptor and inhibits insulin action. J Biol Chem, 277:1531-1537, 2002.

Archer DL. Evidence that ingested nitrate and nitrite are beneficial to health. J Food Prot, 65: 872-875, 2002.

Bryan NS, Alexander DD, Coughlin JR, Milkowski AL, Boffetta P. ingested nitrate and nitrite and stomach cancer risk: an updated ewview. Food Chem Toxicol, 50: 3646-3665, 2012.

Carlstrom M, Larsen FJ, Nystrom T, Hezel M, Borniquel S, Weitzberg E, Lundberg JO. Dietary inorganic nitrate reverses features of metabolic syndrome in endothelial nitric oxide synthasedeficient mice. Proc Natl Acad Sci USA, 107: 17716-17720, 2010.

Carvalho-Filho MA, Ueno M, Hirabara SM, Seabra AB, Carvalheria JBC, Oliveira MG, Velloso LA, Curi R, Saad MJA. S-nitrosation of the insulin receptor, insulin receptor substrate 1, and protein kinase B/Akt. A novel mechanism of insulin resistance. Diabetes, 54: 959-967, 2005.

Dang NT, Mukai R, Yoshida K, Ashida H. D-pinitol and myo-inositol stimulate translocation of glucose transporter 4 in skeletal muscle of C57BL/6 mice. Biosci Biotechnol Biochem, 
Das UN. Insulin: an endogenous cardioprotector. Curr Opin Crit Care, 9: 375-383, 2003.

Draznin B. Molecular mechanisms of insulin resistance: serine phosphorylation of insulin receptor substrate-1 and increased expression of $\mathrm{p} 85 \alpha$. The two sides of a coin. Diabetes, 55: 2392-2397, 2006.

Duplain H, Burcelin R, Sartori C, Cook S, Egli M, Lepori M, Vollenweider P, Pedrazzini T, Nicod P, Thorens B, Scherrer U. Insulin resistance, hyperlipidemia, and hypertension in mice lacking endothelial nitric oxide synthase. Circulation, 104: 342-345, 2001.

Fisher-Wellman KH, Neufer PD. Linking mitochondrial bioenergetics to insulin resistance via redox biology. Trends Endocrin Met, 23: 142-153, 2012.

Guerre-Millo M. Adipose tissue and adipokines: for better or worse. Diabetes Metab,30: 13-19, 2004.

Hess DT, Matsumoto A, Kim SO, Marshall HE, Stamler JS. Protein S-nitrosylation: purview and parameters. Nat Rev Mol Cell Bio, 6: 150-165, 2005.

Hotamisligil GS, Shargill NS, Spiegelman BM. Adipose expression of tumor necrosis factor-alpha: direct role in obesity-linked insulin resistance. Science, 259: 87-91, 1993.

Hotamisligil GS, et al. Increased adiposetissue expression of tumor necrosis factor-alpha in human obesity and insulin resistance. J Clin Invest, 95: 2409-2415, 1995.

Hotamisligil GS, et al. IRS-1-mediated inhibition of insulin receptor tyrosine kinase activity in TNF-alpha- and obesity-induced insulin resistance. Science, 271:665-668, 1996.

Hsu MF, Meng TC. Enhancement of insulin responsiveness by nitric oxide-mediated inactivation of protein-tyrosine phosphatases. J Biol Chem, 285: 7919-7928, 2010.

Ishizuka T, Klepcyk P, Liu S, Panko L, Liu S, Gibbs EM, Friedman JE. Effects of overexpression of human GLUT4 gene on maternal diabetes and fetal growth in spontaneous gestational diabetic C57BLKS/J Lepr(db/+) mice. Diabetes, 48:1061-1069, 1999.

Jiang H, Torregrossa AC, Potts A, Pierini D, Aranke M, Garg HK, Bryan NS. Dietary nitrite improves insulin signaling through GLUT4 translocation. Free Rad Biol Med, 67: 51-57, 2014.

Kashyap SR, Roman LJ, Lamont J, Masters BSS, Bajaj M, Suraamornkul S, Belfort R, Berria R, Kellogg DL, Liu Jr Y, DeFronzo RA. Insulin resistance is associated with impaired nitric oxide synthase activity in skeletal muscle of type 2 diabetic subjects. J Clin Endocrinol Metab, 90: 1100-1105, 2005.

Kanaya Y, Doi T, Sasaki H, Fujita A, Matsuno S, Okamoto K, Nakano Y, Tsujiwaki S, Furuta H, Nishi M, Tsuno T, Taniguchi H, Nanjo K. Rice bran extract prevent the elevation of plasma peroxylipid in KKAy diabetic mice. Diabetes Res Clin Pr, 66S: S157-S160, 2004. 
Kern PA, et al. The expression of tumor necrosis factor in human adipose tissue. Regulation by obesity, weight loss, and relationship to lipoprotein lipase. J Clin Invest, 95: 2111-2119, 1995.

Khoo NKH, Mo L, Zharikov S, Kamga C, Quesnelle K, Golin-Bisello F, Li L, Wang Y, Shiva Sruti. Nitrite augments glucose uptake in adipocytes through the protein kinase A-dependent stimulation of mitochondrial fusion. Free Radic Biol Med, 70: 45-53, 2014.

Kim J, Montagnani M, Koh KK, Quon MJ. Reciprocal relationship between insulin resistance and endothelial dysfunction. Molecular and pathophysiological mechanisms. Circulation, 113: 1888-1904, 2006.

Larsen FJ, Schiffer TA, Borniquel S ,Sahlin K, Ekblom B, Lundberg JO, Weitzberg E. Dietary inorganic nitrate improves mitochondrial efficiency in humans. Cell Metab, 13: 149-159, 2011. de Luca C, Olefsky JM. Inflammation and insulin resistance. FEBS let, 582: 97-105, 2008.

Liu M, Wu K, Mao X, Wu Y, Ouyang J. Astragalus polysaccharide improves insulin sensitivity in KKAy mice: regulation of PKB/GLUT4 signaling in skeletal muscle. J Ethnopharmacol, 127:32-37, 2010.

Lundberg JO, Gladwin MT, Ahluwalia A, Benjamin N, Bryan NS, Butler A, et al. Nitrate and nityrite in biology, nutrition and therapeutics. Nat chem Biol, 5: 865-869, 2009.

Mohler III ER, Hiatt WR, Gornik HL, Kevil CG, Quyyumi A, Haynes WG, Annex BH. Sodium nitrite in patients with peripheral artery and diabetes mellitus: Safty, walking distance and endothelial function. Vasc Med, 19: 9-17, 2014.

Nystrom T, Ortsater H, Huang Z, Zhang F, Larsen FJ, Weitzberg E, Lundberg JO, Sjoholm A. Inorganic nitrite stimulates pancreatic islet blood flow and insulin secretion. Free Radic Biol Med, 53: 1017-1023, 2012.

Ohashi K, Ishikawa H, Ohta Y. Octacosanol ameliorates hyperlipidemia and oxidative stress in KKAy mice with type 2 diabetes. J Anal Bio-Sci, 34:223-233, 2011.

Ohtake K, Ishiyama Y, Uchida H, Muraki E, Kobayashi J. Dietary nitrite inhibits early glomerular injury in streptozotocin-induced diabetic nephropathy in rats. Nitric Oxide, 17:75-81, 2007.

Ohtake K, Koga M, Uchida H, Sonoda K, Ito J, Uchida M, Natsume H, Kobayashi J. Oral nitrite ameliorates dextran sulfate sodium-induced acute experimental colitis in mice. Nitric Oxide, 23: 65-73, 2010.

Okuno A, Tamemoto H, Tobe K, Ueki K, Mori Y, Iwamoto K, Umesono K, Akanuma Y, Fujiwara T, Horikoshi H, Yazaki Y, Kadowaki T. Troglitazone increases the number of small adipocytes without the change of white adipose tissue mass in obese Zucker rats. J Clin Invest, 101: 1354-1361, 1998.

Paz K, et al. A molecular basis for insulin resistance. Elevated serine/threonine phosphorylation of IRS-1 and IRS-2 inhibits their binding to the juxtamembrane region of the insulin receptor and impairs their ability to undergo insulin-induced tyrosine phosphorylation. J Biol Chem, 272: 29911-29918, 1997.

Reyna SM, Ghosh S, Tantiwong P, Meka CSR, Eagan P, Jenkinson CP, Cersosimo E, DeFronzo RA, 
Coletta DK, Sriwijitkamol A, Musi N. Elevated toll-like receptor 4 expression and signaling in muscle from insulin-resistant subjects. Diabetes, 57: 2595-2602, 2008.

Richey JM. The vascular endothelium, a benign restrictive barrier? No! Role of nitric oxide in regulating insulin action. Diabetes, 62: 4006-4008, 2013.

Rizzo NO, Maloney E , PhamM, Luttrell I, Wessells H, Tateya S, Daum G, Handa P, Schwartz MW, Kim F. Reduced NO-cGMP Signaling Contributes to Vascular Inflammation and Insulin Resistance Induced by High-Fat Feeding. Arterioscler Thromb Vasc Biol. 30: 758-765, 2010.

Saghizadeh M, et al. The expression of TNF alpha by human muscle. Relationship to insulin resistance. J Clin Invest, 97: 1111-1116, 1996.

Sansbury BE, Hill BG. Regulation of obesity and insulin resistance by nitric oxide. Free Radic Biol Med, 73: 383-399, 2014.

Saltiel R, Pessin JE. Insulin signaling pathways in time and space. Trends Cell Biol. 2: 65-71, 2002.

Srinivasam K, Ramarao P. Animal models in type 2 diabetes research: An overview. Indian J Med Res, 125: 451-472, 2007.

Tajima S, Ikeda Y, Sawada K, Yamano N, Horinouchi Y, Kihira Y, Ishizawa K, Izawa-Ishizawa Y, Kawazoe K, Tomita S, Minakuchi K, Tsuchiya K, Tamaki T. Iron reduction by deferoxamine leads to amelioration of adiposity via the regulation of oxidative stress and inflammation in obese and type 2 diabetes KKAy mice. Am J Physiol Endocrinol Metab, 302: E77-E86, 2012.

Tiganis T. Reactive oxygen species and insulin resistance: the good, the bad and the ugly. Trends Pharmacol Sci, 32: 82-89, 2011.

Uysal KT, Wiesbrock SM, Marino MW, Hotamisligil GS. Protection from obesityinduced insulin resistance in mice lacking TNFalpha function. Nature, 389: 610-614, 1997.

Wang H, Wang AX, Aylor K, Barrett EJ. Nitric oxide directly promotes vascular endothelial insulin transport. Diabetes, 62: 4030-4042, 2013.

White MF. The insulin signalling system and the IRS proteins. Diabetologia. 40(Suppl. 2): S2-S17, 1997.

Yin MJ, Yamamoto Y, Gaynor RB. The anti-inflammatory agents aspirin and salicylateinhibit the activity of I (kappa) B kinase-beta. Nature, 396: 77-80, 1998.

\section{Legends}

Figure 1

Time course of changes in body weight (A), food intake (B), and fasting blood glucose levels (C) with or without dietary nitrite.

$\bullet: \quad \mathrm{KKA}^{\mathrm{y}}-0 \mathrm{mg} / \mathrm{L}, \quad \boldsymbol{\square}: \mathrm{KKA}^{\mathrm{y}}-50 \mathrm{mg} / \mathrm{L}, \quad \boldsymbol{\Delta}: \mathrm{KKA}^{\mathrm{y}}-150 \mathrm{mg} / \mathrm{L}, \diamond: \quad \mathrm{C} 57 \mathrm{BL} / 6 \mathrm{~J}-0 \mathrm{mg} / \mathrm{L}, \quad \Delta:$ $\mathrm{C} 57 \mathrm{BL} / 6 \mathrm{~J}-150 \mathrm{mg} / \mathrm{L}$. The results are displayed as means $\pm \mathrm{SE}(\mathrm{n}=8-10),{ }^{*} P<0.05$ vs. $\mathrm{C} 57 \mathrm{BL} / 6 \mathrm{~J}-0 \mathrm{mg} / \mathrm{L}$. 
Figure 2

Effects of dietary nitrite on the time course of blood glucose levels and AUC following IPGTT.

(A) blood glucose concentrations $(\mathrm{mg} / \mathrm{mL})$ following IPGTT, (B) AUC (mg/dL $\times$ min) of blood

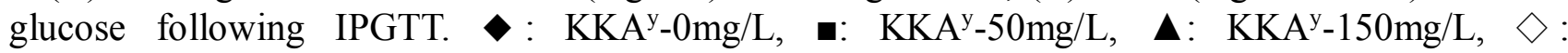
$\mathrm{C} 57 \mathrm{BL} / 6 \mathrm{~J}-0 \mathrm{mg} / \mathrm{L}, \Delta: \mathrm{C} 57 \mathrm{BL} / 6 \mathrm{~J}-150 \mathrm{mg} / \mathrm{L}$. The results are displayed as means $\pm \mathrm{SE}(\mathrm{n}=8-10),{ }^{*} P<$ 0.05 vs. $\mathrm{KKA}^{\mathrm{y}}-0 \mathrm{mg} / \mathrm{L}$. AUC: area under the curve (the area under the blood glucose concentration-time curve following IPGTT). IPGTT: intraperitoneal glucose tolerance test.

Figure 3

Effects of dietary nitrite on fasting blood levels of glucose and insulin, and insulin sensitivity.

(A) fasting blood glucose, (B) fasting plasma insulin, (C) HOMA-IR score, with or without dietary nitrite in KKAy diabetic and $\mathrm{C} 57 \mathrm{BL} / 6 \mathrm{~J}$ control mice. The results are displayed as means $\pm \mathrm{SE}$ $(\mathrm{n}=8-10),{ }^{*} P<0.05$ vs. $\mathrm{KKA}^{\mathrm{y}}-0 \mathrm{mg} / \mathrm{L}$. HOMR-IR: The index of homeostasis model assessment of insulin resistance, calculated as fasting plasma glucose $[\mathrm{mmol} / \mathrm{l}] \times$ fasting plasma insulin [mU/1] / 22.5 .

Figure 4

Effects of dietary nitrite on the morphology of adipose tissues.

(A) the ratio of adipose tissue mass to body weight (\%), (B) area of adipocyte $\left(\mu \mathrm{m}^{2}\right)$, The results are displayed as means $\pm \mathrm{SE}(\mathrm{n}=4-8),{ }^{*} P<0.05$ vs. $\mathrm{KKA}^{\mathrm{y}}-0 \mathrm{mg} / \mathrm{L}$. (C) the representative light microscopic image of HE-stained adipose tissues of KKAy and C57BL/6J mice with or without dietary nitrite (bar: ??? $\mu \mathrm{m}$ ), and the distribution histogram of adipocyte size. The area of adipocyte was traced and measured in 500 cells/ mouse ( $n=4 /$ groups) using the Image $J$ software program.

Figure 5

Effects of dietary nitrite on the transcriptional levels of proinflammatory cytokines in visceral adipose tissues.

(A) MCP-1, (B) TNF- $\alpha$. The data is presented by standard values for levels of GAPDH mRNA expression in the adipose tissues studied. The results are displayed as means $\pm \mathrm{SE}(\mathrm{n}=6-8),{ }^{*} P<0.05$ vs. $\mathrm{KKA}^{\mathrm{y}}-0 \mathrm{mg} / \mathrm{L}$.

Figure 6

Sequential phosphorylation of P85/Akt of skeletal muscle and subsequent expression of GLUT4 on the cell membrane of skeletal muscle.

The data of western blots are representative of three independent experiments. The band intensities of phosphorylation were quantified by comparison to the total protein. (A): $\mathrm{p} 85-\mathrm{Tyr}^{458}$ to $\mathrm{p} 85$ and (B): Akt-Ser ${ }^{473}$ to Akt. The band intensities of GLUT4 were also quantified by comparison to housekeeping protein GAPDH (C). The results are displayed as means $\pm \mathrm{SE}(\mathrm{n}=6-8) * P<0.05$ vs. $\mathrm{KKA}^{\mathrm{y}}-0 \mathrm{mg} / \mathrm{L}$

Figure 7

Effects of dietary nitrite on the levels of nitrite and nitrate in skeletal muscle.

The concentrations of nitrite (A) and nitrate (B) in skeletal muscle. The results are displayed as means $\pm \mathrm{SE}(\mathrm{n}=6-8),{ }^{*} P<0.05$ vs. $\mathrm{KKA}^{\mathrm{y}}-0 \mathrm{mg} / \mathrm{L}$ 
Figure 1

(A)

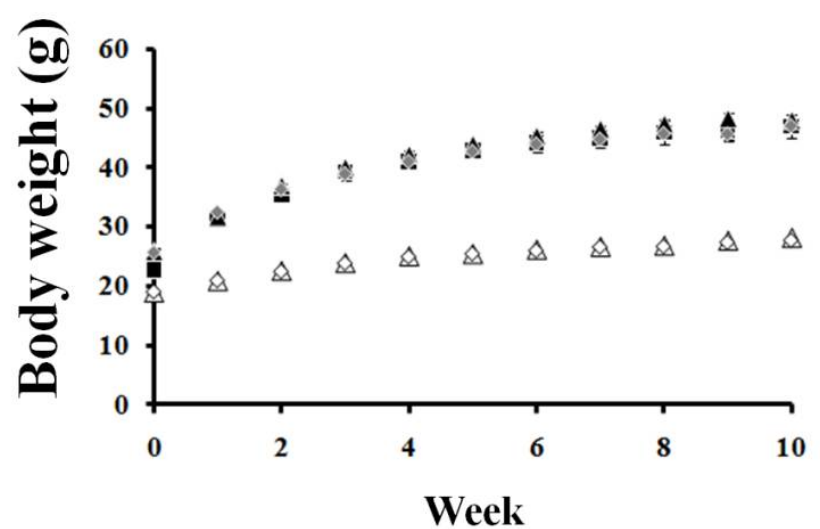

(B)
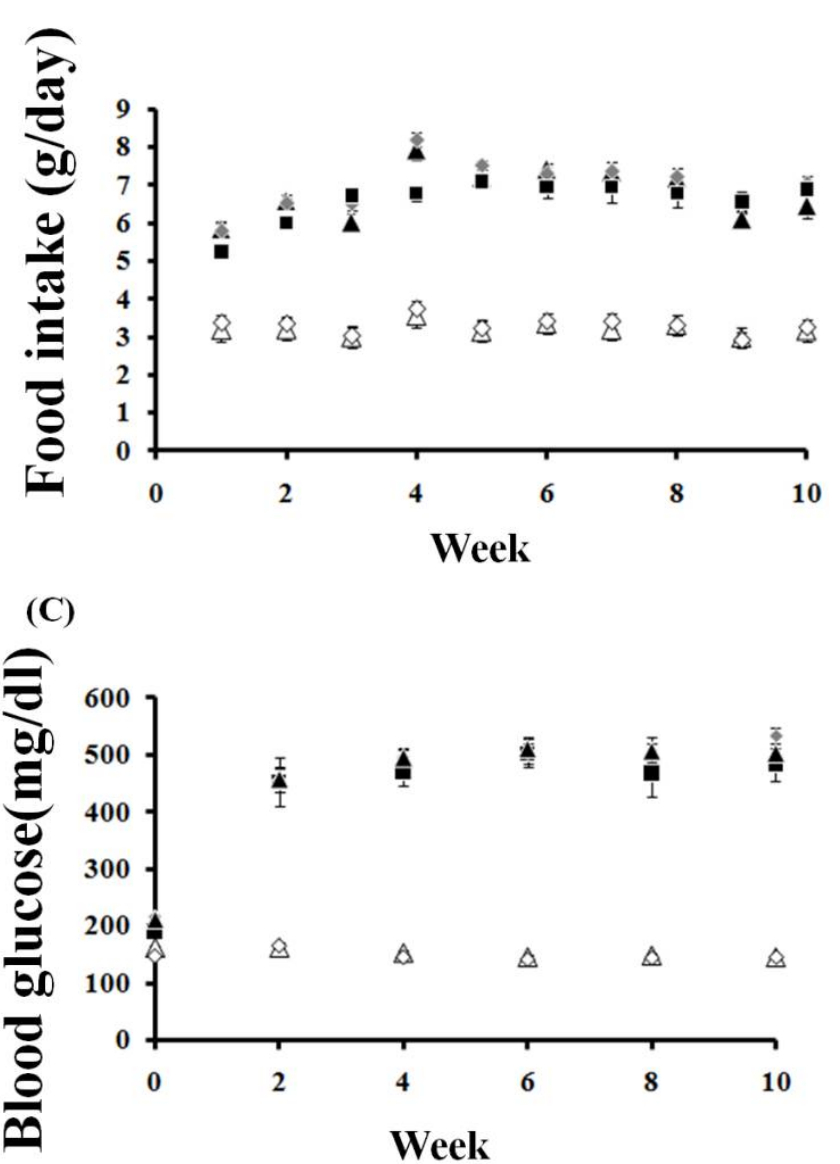


\section{Figure 2}

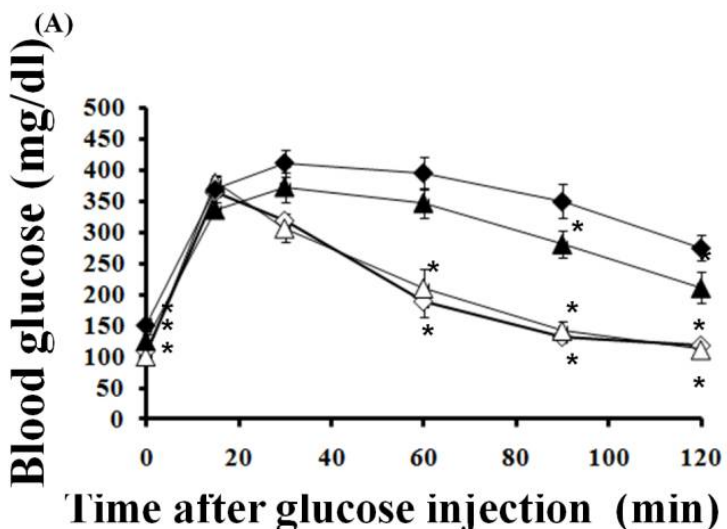

(B)

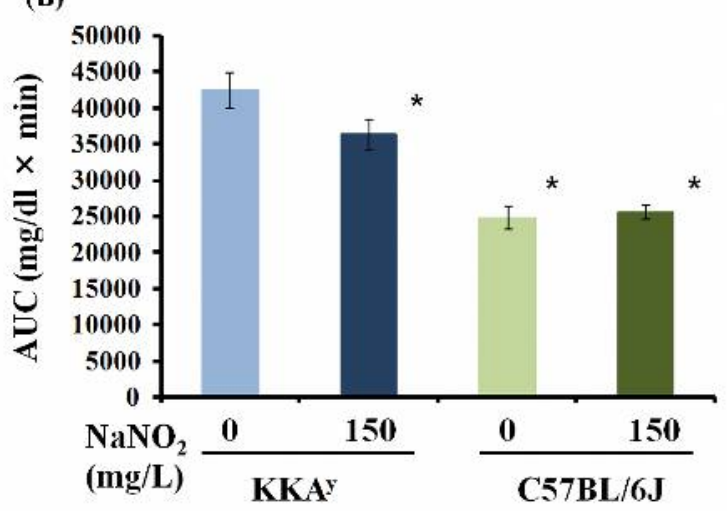




\section{Figure 3}
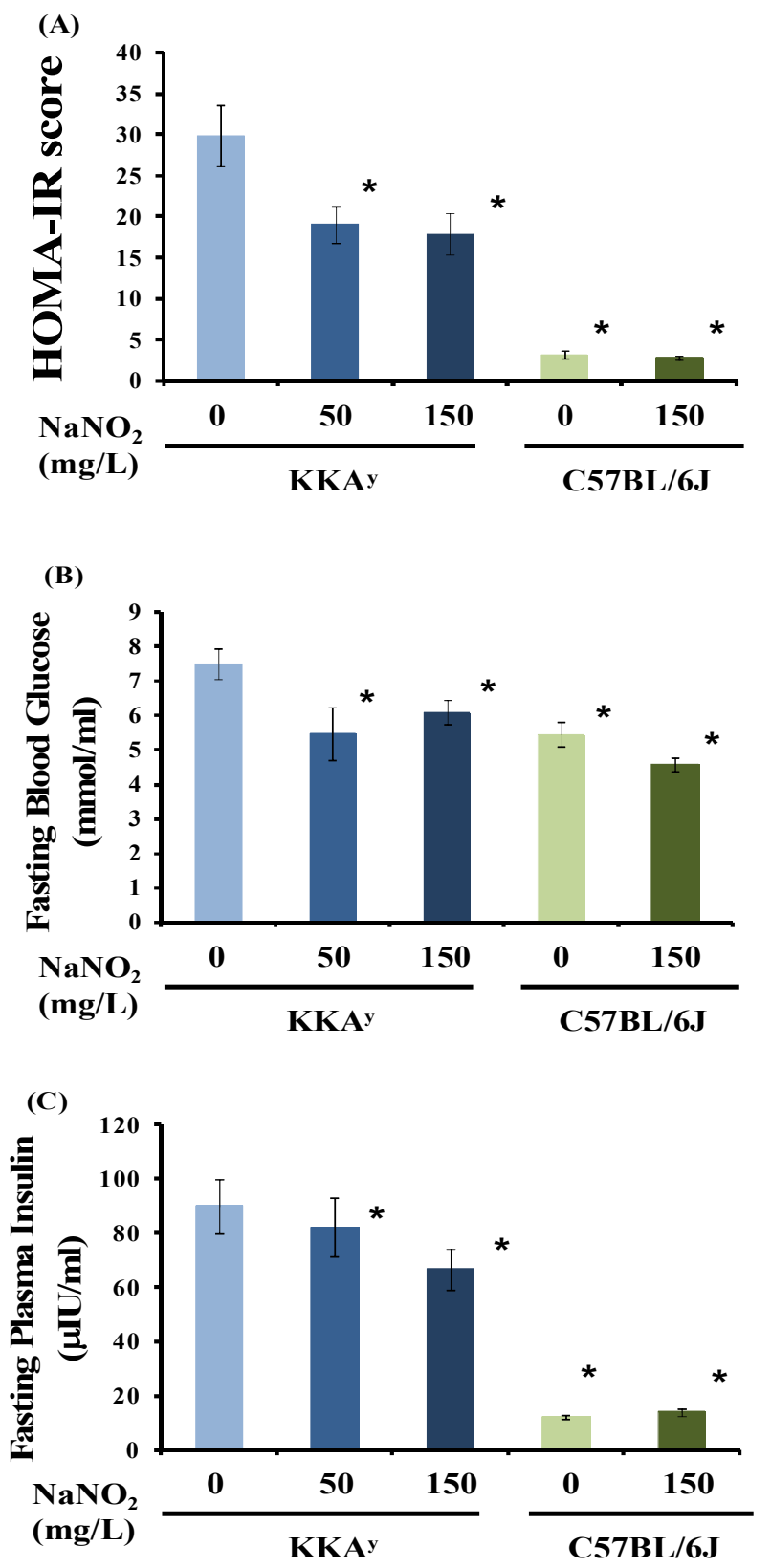


\section{Figure 4}
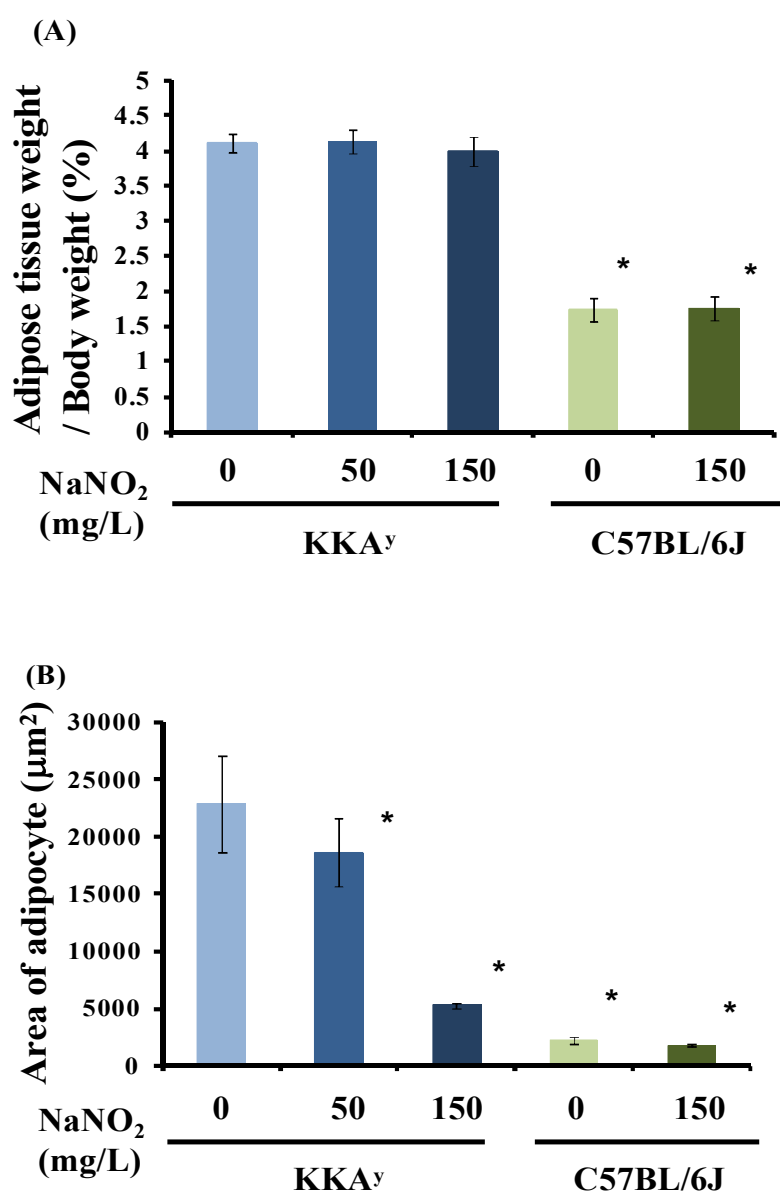


\section{Figure 4}

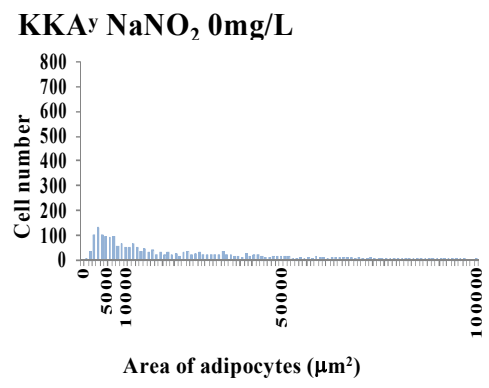

\section{C57BL/6 0mg/L}

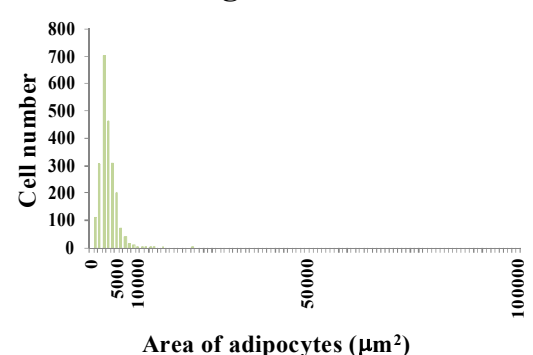

(B)

KKAy $\mathrm{NaNO}_{2}$ 0mg/L

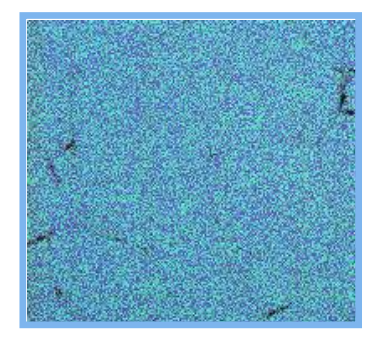

C57BL/6 NaNO $0 \mathrm{mg} / \mathrm{L}$

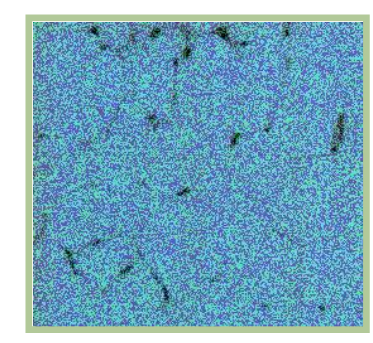

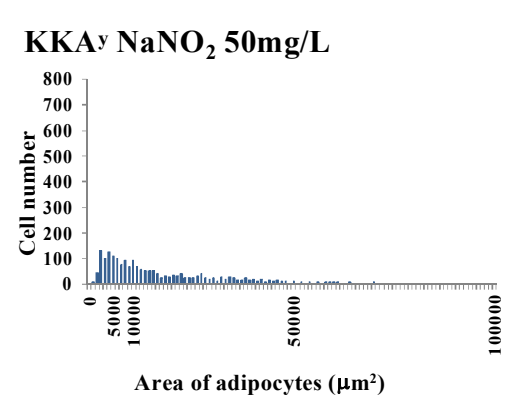

$\mathrm{KKA}^{y} \mathrm{NaNO}_{2}$ 150mg/L

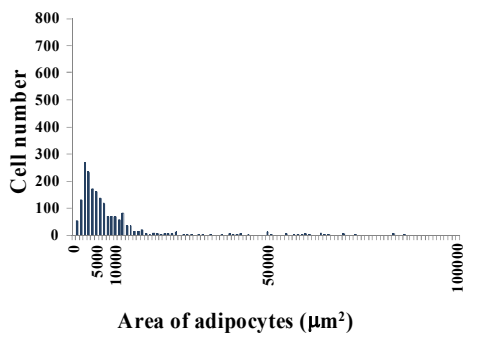

C57BL/6 150mg/L

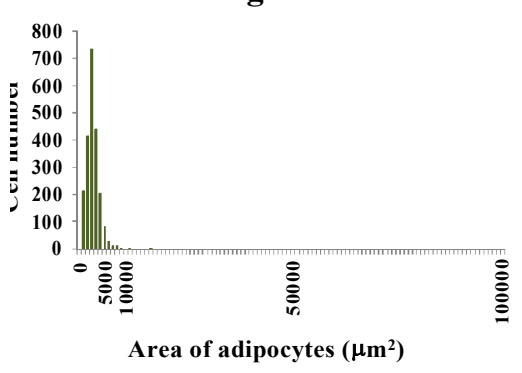

Area of adipocytes $\left(\mu \mathbf{m}^{2}\right)$

$\mathrm{KKA}^{y} \mathrm{NaNO}_{2} 50 \mathrm{mg} / \mathrm{L}$

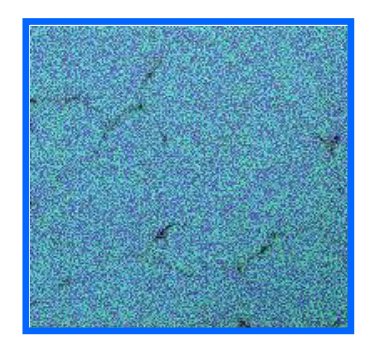

KKAy $\mathrm{NaNO}_{2}$ 150mg/L

C57BL/6 NaNO $150 \mathrm{mg} / \mathrm{L}$

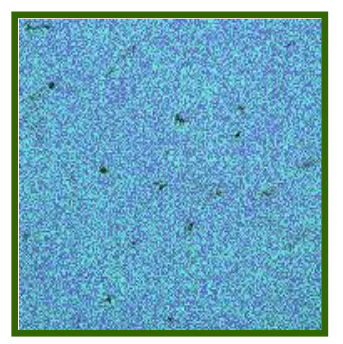


Figure 5 (A)

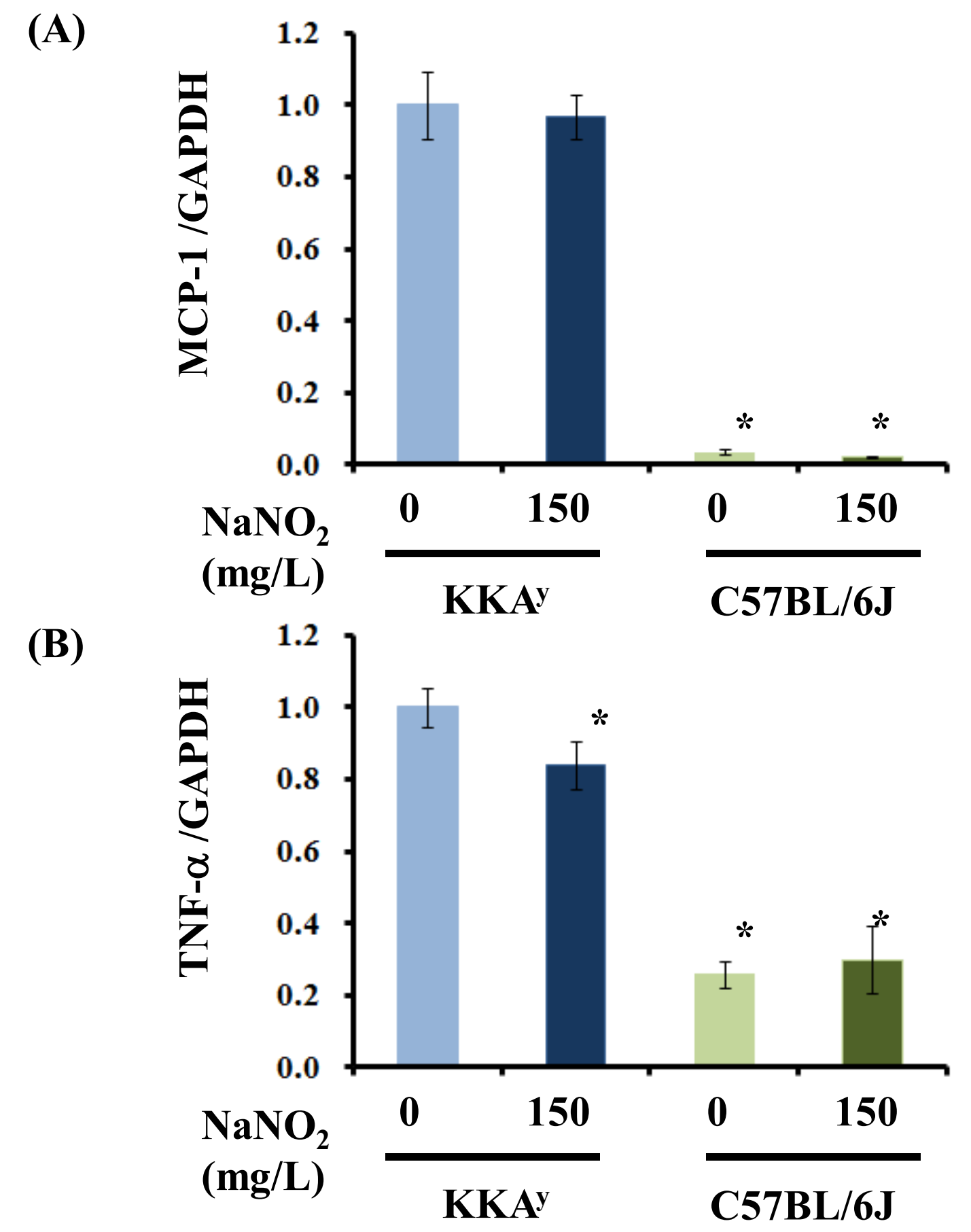




\section{Figure 6}

(A)

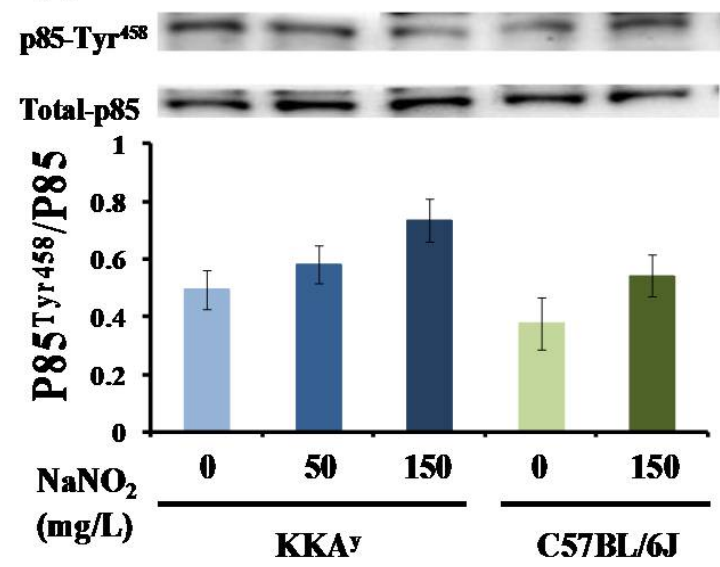

(B)

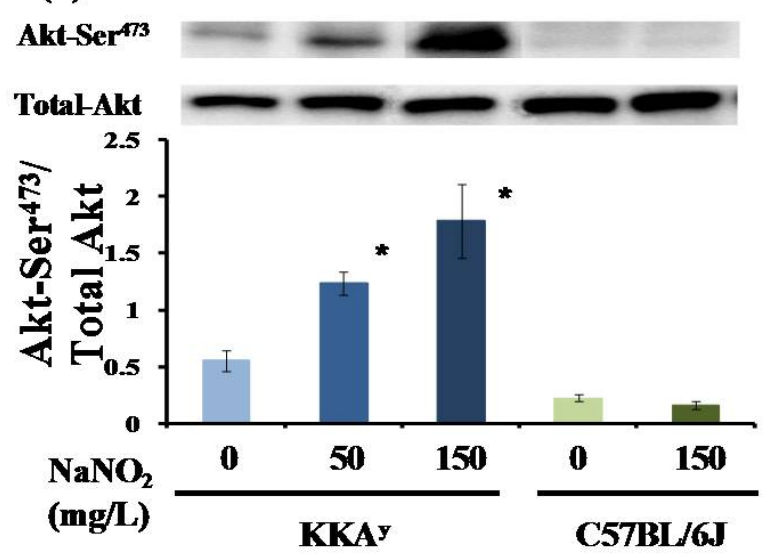

(C)

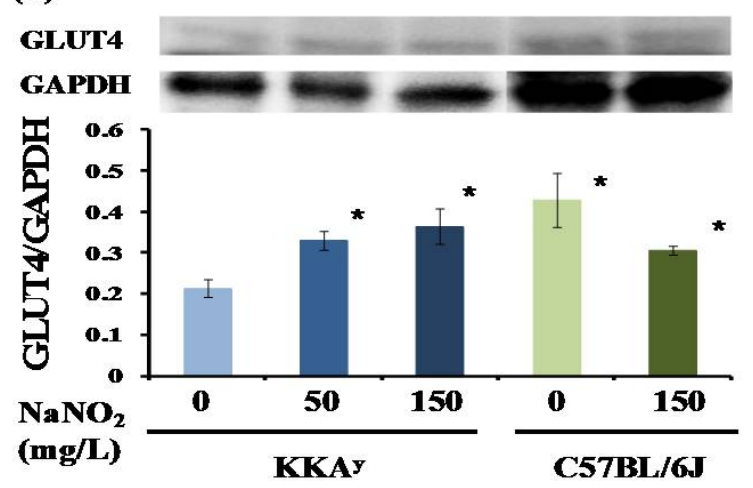




\section{Figure 7}
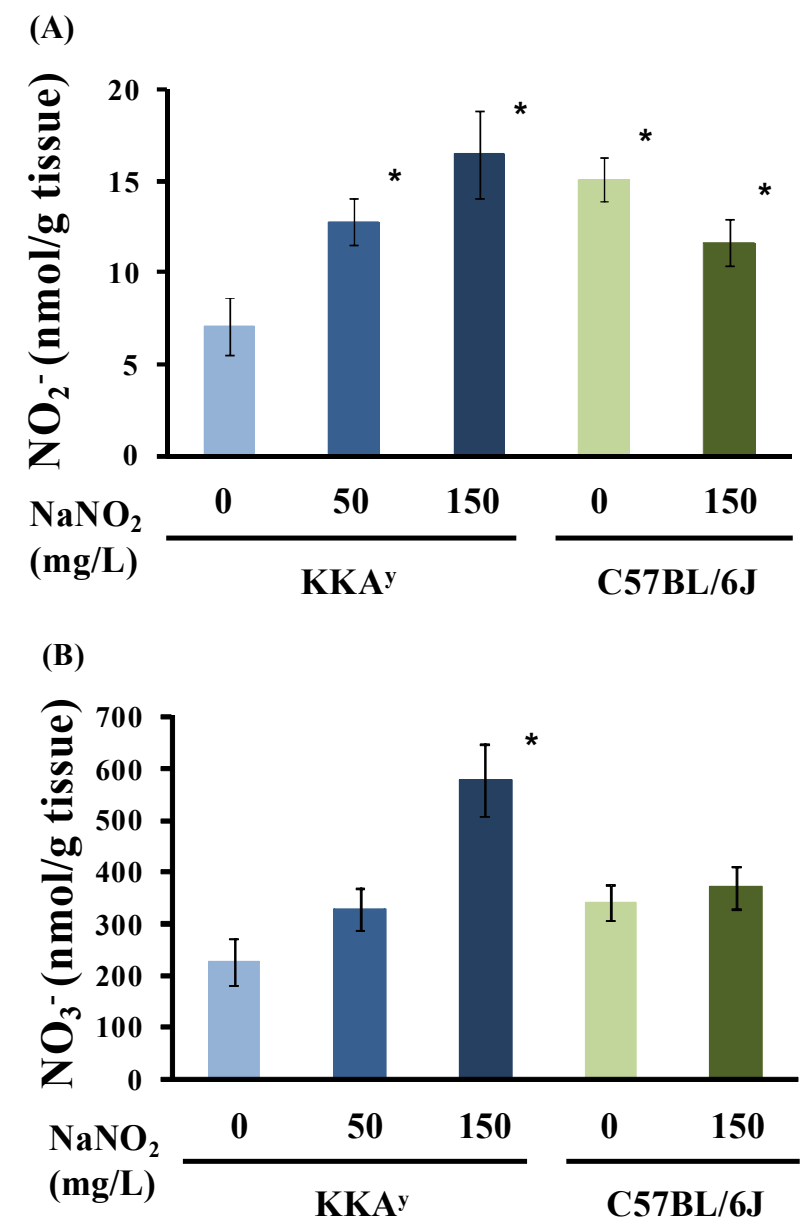